\title{
RESPON HUJAN LEBAT DAN KENAIKAN TINGGI MUKA LAUT TERHADAP PREDIKSI LUASAN BANJIR ROB DI SEMARANG (STUDI KASUS 3 - 5 DESEMBER 2018)
}

\section{RESPONSE OF HEAVYRAINFALLAND HIGHWATER LEVELTO COASTALINUNDATION AREA PREDICTION IN SEMARANG (CASE STUDY 3 - 5 DECEMBER 2018)}

\author{
Usman Efendi ${ }^{1}$, Aries Kristianto ${ }^{2}$, \& Bayu Edo Pratama ${ }^{3}$ \\ ${ }^{1}$ Stasiun Meteorologi Maritim Tanjung Emas Semarang \\ Badan Meteorologi Klimatologi dan Geofisika (BMKG), Jl. Yos Sudarso No. 58, Semarang \\ ${ }^{2}$ Sekolah Tinggi Meteorologi Klimatologi dan Geofisika \\ Jl. Perhubungan I No.5, Tangerang Selatan \\ ${ }^{3}$ Pusat Meteorologi Maritim BMKG \\ Jl. Angkasa I, No.2 Kemayoran, Jakarta Pusat \\ e-mail : usman.ngc225@gmail.com
}

Diterima tanggal: 2 Januari 2021 ; diterima setelah perbaikan: 26 Agustus 2021 ; Disetujui tanggal: 8 Oktober 2021

\begin{abstract}
ABSTRAK
Wilayah pesisir merupakan lingkungan yang menyimpan beragam kekayaan hayati dan non hayati. Disisi lain, wilayah pesisir juga memiliki kerentanan bencana alam yang tinggi, salah satunya adalah banjir pesisir atau banjir rob. Banjir rob disebabkan akibat kenaikan Tinggi Muka Laut (TML) sehingga menggenangi daerah rendah di sekitar pantai. Luas wilayah yang tergenang banjir rob semakin bertambah apabila bersamaan dengan terjadinya hujan lebat. Salah satu wilayah di Indonesia yang rentan terhadap dampak banjir rob adalah kota Semarang. Banjir rob menyebabkan kualitas lingkungan dan kehidupan masyarakat di wilayah pesisir menurun drastis. Penelitian ini bertujuan untuk memprediksi banjir rob berbasis model Hidrodinamika LISFLOOD FP di pesisir Semarang. LISFLOOD FP menggunakan pendekatan difusi gelombang persamaan St Venant dengan data raster Digital Elevation Model (DEM) sebagai domain serta data detail aliran air untuk menyimulasikan dinamika banjir. Model LISFLOD FP menggunakan data prediksi tinggi muka laut dari model Delft3D dan prediksi intensitas hujan dari model WRF untuk memprediksi banjir rob. Model banjir rob dijalankan dengan 2 variasi skema, pertama model tanpa memperhitungkan data intensitas hujan dan kedua model dengan memperhitungkan data intensitas hujan. Hasil penelitian menunjukkan bahwa model banjir rob untuk kedua skema menunjukkan kedalaman banjir yang hampir sama sekitar 0,2 - 1,5 m. Model banjir rob dengan memperhitungkan data intensitas hujan menunjukkan luasan banjir yang lebih tinggi sebesar 5,6\% dibandingkan dengan model banjir rob tanpa memperhitungkan data intensitas hujan.
\end{abstract}

Kata kunci: Wilayah pesisir, banjir rob, tinggi muka laut, model LISFLOOD FP.

\section{ABSTRACT}

A Coastal area is an environment that stores a variety of biological and non-biological wealth. On the other hand, coastal areas also have high vulnerability to natural disasters, for example, coastal inundation. Coastal inundation is caused by an increase in Sea Level so that it inundates low areas around the coast. The inundated area increases when it coincides with heavy rain. Semarang is one of the cities in Indonesia that is prone to coastal inundation. Coastal inundation reduces the quality of the environment and community life in coastal areas. This study aims to predict coastal inundation based on the LISFLOOD FP Hydrodynamic model on the coast of Semarang. LISFLOOD FP uses the St Venant wave diffusion equation approach, Digital Elevation Model (DEM) raster data as the domain, and detailed water flow data to simulate flood dynamics. The LISFLOD FP model used sea-level prediction data from the Delft $3 D$ model and rainfall intensity prediction from the WRF model to predict coastal inundation. The coastal inundation model had two variations of the scheme, the first model used rainfall intensity data, and the second model did not use rainfall intensity data. The results showed that the coastal inundation model for the two schemes showed almost the same flood depth of $0.2-1.5 \mathrm{~m}$. The coastal inundation model that used rainfall intensity shows a higher flood area of $5.6 \%$ compared to the model without considering the rainfall intensity data.

Keywords: Coastal area, coastal inundation, sea level, LISFLOOD FP model.

Respon Hujan Lebat dan Kenaikan Tinggi Muka Laut Terhadap Prediksi Luasan Banjir Rob di Semarang (Studi Kasus 3 - 5 Desember 2018) - Usman Efendi, Aries Kristianto, \& Bayu Edo Pratama 


\section{PENDAHULUAN}

Wilayah pesisir merupakan merupakan lingkungan yang sangat dinamis dengan beragam aktivitas dan fenomena alam yang ada didalamnya. Wilayah pesisir memiliki kondisi ekosistem, geomorfologi, dan iklim yang dipengaruhi oleh interaksi antara proses yang terjadi di darat dan di laut. Beragam potensi kekayaan dan sumber daya alam tersimpan di kawasan ini, seperti sumber perikanan global, pusat pembangunan transportasi dan industri, sumber beragam mineral dan produk geologi seperti minyak dan gas, sebagai destinasi wisata, serta sebagai tempat bagi keanekaragaman hayati dan ekosistem yang didukung sistem yang terjadi di bumi (Crossland et al., 2005; Marfai \& King, 2008).

Melimpahnya kekayaan dan keanekaragaman sumber daya alam menyebabkan aktivitas penduduk terkonsentrasi di wilayah pesisir. Diperkirakan setengah populasi manusia tinggal di dekat daerah pesisir. Meskipun kepadatan penduduk di wilayah pesisir sangat bervariasi antara satu daerah dengan daerah lain, terdapat kecenderungan peningkatan jumlah penduduk di wilayah tersebut. Pengembangan infrastruktur di wilayah pantai yang berlebihan akibat urbanisasi secara signifikan meningkatkan kerentanan terhadap erosi dan banjir di kawasan pesisir (rob). Keadaan ini diperparah dengan perubahan iklim global yang menyebabkan kenaikan muka air laut dan frekuensi terjadinya badai (Crossland et al., 2005; Masselink \& Gehrels, 2014).

Banjir rob terjadi akibat naiknya Tinggi Muka Laut (TML) yang dipengaruhi oleh pasang surut air laut dan storm surge sehingga menggenangi daerah rendah di sekitar pantai. Banjir rob diperkirakan akan menjadi semakin besar akibat adanya fenomena kenaikan suhu permukaan laut yang diikuti oleh pemuaian massa air laut dan mencairnya lapisan es sehingga mempercepat kenaikan TML. Fenomena tersebut menjadi persoalan penting yang dihadapi negara-negara kepulauan di dunia. Kenaikan TML pada tahun 2100 diperkirakan bertambah sebesar $43 \mathrm{~cm}$ hingga $84 \mathrm{~cm}$ atau sekitar 0,4 $\mathrm{cm} /$ tahun hingga 1,5 cm/tahun (Kobayashi, 2003; Kumar, 2006; Wolf, 2008; Marfai et al., 2013; Intergovernmental Panel on Climate Change [IPCC], 2019).

Banjir rob menyebabkan kualitas lingkungan dan kehidupan masyarakat menurun drastis, dan luasan lahan genangan rob memiliki kecenderungan semakin bertambah dengan frekuensi yang semakin tinggi. Jalur
Pantura yang menjadi penghubung utama Kota Surabaya dan Jakarta juga terganggu akibat adanya genangan banjir rob. Kemacetan panjang seringkali terjadi akibat genangan air laut yang mencapai jalan raya. Analisis terkait bencana banjir rob penting dilakukan dalam konteks pengelolan pesisir guna mendukung pembangunan daerah (Kraas, 2007; Ward et al., 2011; Ramadhany et al., 2012).

Pesisir Semarang merupakan salah satu wilayah yang selalu menghadapi bencana banjir rob. Daerah yang tergenang banjir rob akan semakin luas apabila terjadi bersamaan dengan hujan lebat (Susanti et al., 2017). Sementara itu, penelitian terkait pemodelan banjir rob di Semarang umumnya belum memperhitungkan pengaruh curah hujan. Penelitian yang dilakukan oleh Nugroho (2013) misalnya, prediksi luasan genangan banjir rob di Semarang dibuat berdasarkan skenario kenaikan TML dan penurunan muka tanah menggunakan model GIS. Pemodelan banjir rob di Semarang juga dilakukan oleh Sanjaka et al. (2013) menggunakan model Hidrodinamika Mike 21 dengan input data TML.

Pada penelitian ini akan dilakukan prediksi sebaran banjir rob di wilayah Pesisir Semarang berbasis model LISFLOOD FP. Berbeda dengan penelitian sebelumnya, prediksi banjir rob ini menggunakan input data prediksi TML dan data prediksi intensitas hujan sehingga prediksi banjir yang dihasilkan sudah memperhitungkan pengaruh curah hujan. Keluaran model LISFLOOD FP berupa data sebaran spasial serta time series perkembangan luasan wilayah yang berpotensi terdampak banjir rob. Hasil penelitian ini dapat dimanfaatkan sebagai bahan pertimbangan dalam mengambil kebijakan guna mengurangi dampak yang ditimbulkan banjir rob.

\section{BAHAN DAN METODE}

Penelitian ini akan difokuskan di Pesisir Semarang seperti yang terlihat pada peta penelitian Gambar 1 . Wilayah penelitian dibatasi untuk kecamatan yang memiliki potensi terjadi banjir rob menurut Buchori et al. (2018), yaitu Kecamatan Tugu, Semarang Utara, Semarang Timur, Semarang Tengah, Semarang Barat, Pedurungan, Genuk, serta Gayamsari. Waktu penelitian dipilih pada 3 - 5 Desember 2018 dimana pada saat itu terjadi pasang air laut yang disertai hujan lebat. Perangkat lunak pemodelan yang digunakan terdiri dari Weather Research and Forecasting (WRF), Delft3D, serta LISFLOOD FP. Adapun data yang digunakan dalam penelitian ini terdiri dari: 


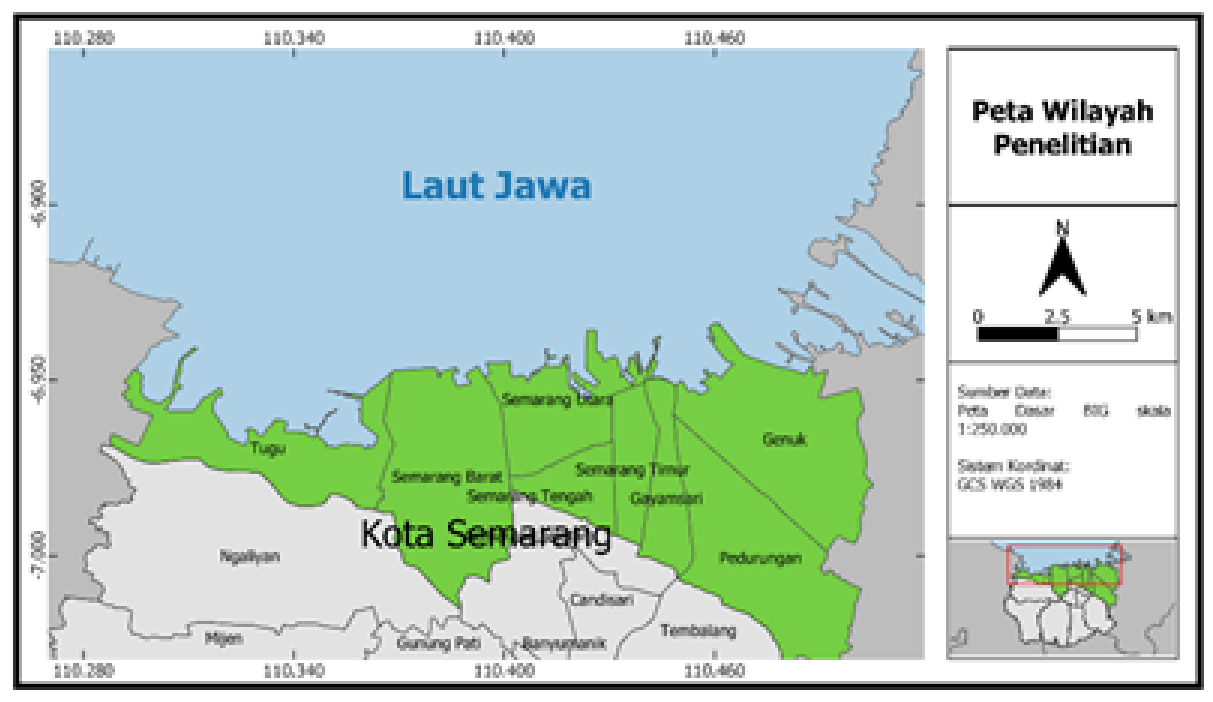

Gambar 1. Peta wilayah penelitian.

Figure 1. Map of the research area.

Sumber: Dokumentasi pribadi

- Data Global Forecast System (GFS) dengan data inisial jam 12 UTC 2 Desember 2018 hingga forecast 84 jam kedepan dengan resolusi temporal 3 jam dan resolusi spasial $0,25^{\circ} \times 0,25^{\circ}$ yang diperoleh dari National Centers for Environmental Prediction (NCEP).

- Data intensitas hujan yang diperoleh dari Stasiun Meteorologi Maritim Tanjung Mas.

- Data batimetri resolusi $180 \mathrm{~m}$, data DEM resolusi $8 \mathrm{~m}$, serta data observasi TML 3 - 5 Desember 2018 yang diperoleh dari Badan Informasi Geospasial (BIG).

WRF merupakan model numerik yang dirancang untuk melakukan simulasi atmosfer secara fleksibel dan portable (Skamarock et al., 2008). Pada penelitian ini model WRF digunakan untuk memprediksi parameter meteorologi dengan inputan data GFS. Keluaran model WRF diambil untuk Mean Sea Level Pressure (MSLP), arah dan kecepatan angin $10 \mathrm{~m}$, serta intensitas curah hujan dengan resolusi temporal 1 jam dan resolusi spasial $1 \mathrm{~km}$. Data tersebut selanjutnya digunakan sebagai input data model Delft3D dan LISFLOOD FP.

Delft3D merupakan framework pemodelan hidrodinamika untuk menyimulasikan arus, gelombang, transpor sedimen, kualitas air, serta perkembangan morfologi di wilayah pesisir, sungai, danau, dan muara (Deltares, 2014a; Deltares, 2014b). Model Delft3D

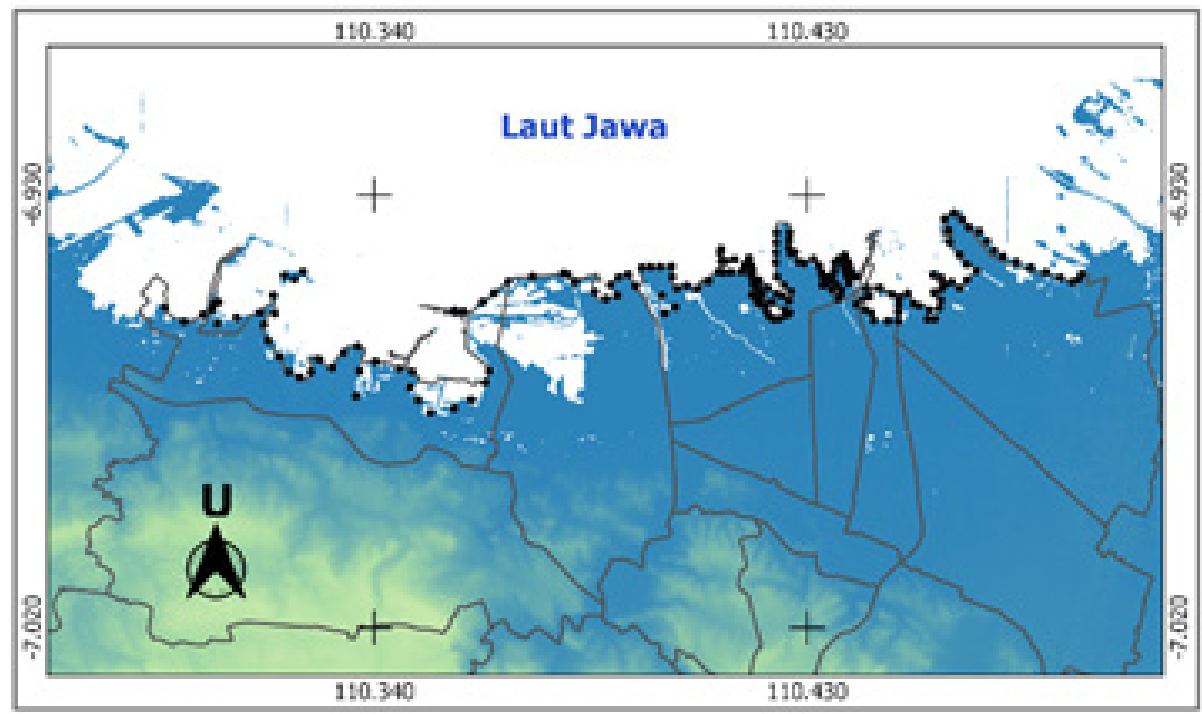

Gambar 2. Lokasi kondisi batas untuk data TML model LISFLOOD FP (titik warna hitam).

Figure 2. Location of sea level boundary conditions for the LISFLOOD FP model (black dot) Sumber: hasil analisis pada penelitian ini. 
pada penelitian ini dijalankan dengan domain batimetri pesisir Semarang resolusi $180 \mathrm{~m}$ serta dengan inputan data angin $10 \mathrm{~m}$ dan MSLP keluaran model WRF. Dari model Delft3D ini didapatkan data time series TML yang diekstrak di sepanjang Pesisir Semarang sebagai input data kondisi batas model LISFLOOD FP. Sebaran data TML tersebut dapat dilihat pada Gambar 2.

Data prediksi curah hujan dan TML diverifikasi terhadap data observasi menggunakan metode statistik, yaitu analisis korelasi Pearson (selanjutnya disebut analisis korelasi), linear bias, serta Root Mean Square Error (RMSE). Analisis korelasi digunakan untuk mengetahui keeratan hubungan antara data prediksi dan observasi, dengan nilai koefisien berada pada rentang -1 hingga 1 . Linear bias berfungsi untuk mengetahui apakah nilai suatu prediksi cenderung diatas nilai observasi (overestimate) atau cenderung dibawah nilai observasi (underestimate). Sementara itu, RMSE digunakan untuk mengetahui besarnya error data prediksi terhadap observasi (Safril et al., 2013; Robertson \& Vitart, 2018; Aulia et al., 2018).

LISFLOOD FP merupakan model model banjir berbasis storage-cell 2 dimensi menggunakan pendekatan difusi gelombang persamaan St Venant. Model tersebut menggunakan data raster DEM sebagai domain serta data detail aliran air untuk menyimulasikan dinamika banjir. Kedalaman genangan air pada grid model dihitung berdasarkan prinsip kontinuitas hidraulik, sementara aliran air di dataran banjir mengikuti perbedaan ketinggian hidraulik diantara sel data raster yang digunakan. Laju aliran air pada model dihitung berdasarkan ketinggian permukaan air diatas permukaan domain dengan mempertimbangkan koefisien gesek Manning (Bates et al., 2005; Dabrowa et al., 2015).

Perubahan kedalaman air, h, pada sel i,j yang dihitung pada waktu $t$, dapat dituliskan melalui Persamaan 1 (Neal et al., 2012).

$$
h_{i, j}^{t+\Delta t}=h_{i, j}^{t}+\Delta t \frac{Q_{x i, j-1}^{t}-Q_{x i, j}^{t}+Q_{y i, j-1}^{t}-Q_{y i, j}^{t}}{\Delta x^{2}}
$$

Dimana $\Delta \mathrm{x}$ adalah ukuran sel, $\Delta \mathrm{t}$ adalah time step model, dan Qt adalah aliran antar sel yang dituliskan dalam Persamaan 2.

$$
Q^{t}=\frac{q^{t}-g h_{\text {flow }}^{t} \Delta t \frac{\Delta\left(h^{t}+z\right)}{\Delta x}}{\left(1+g h_{\text {flow }}^{t} \Delta t n^{2}\left|q^{t-\Delta t}\right| /\left(h_{\text {flow }}^{t}\right)^{10 / 3}\right) \Delta x}
$$

dimana,

$\mathrm{h}_{\text {flow }} \quad$ : kedalaman antar sel dimana air dapat mengalir $\mathrm{z} \quad$ : elevasi sel raster

n : koefisien kekasaran Manning (pada penelitian ini digunakan $n=0,05$ untuk seluruh domain)

g : percepatan gravitasi

q : : flux antar sel dari time step sebelumnya

Model LISFLOOD FP pada penelitian ini dijalankan pada data DEM resolusi $8 \mathrm{~m}$. Input data aliran air untuk mensimulasikan banjir rob berasal dari data prediksi TML keluaran model Delft3D serta data prediksi intensitas hujan keluaran model WRF. Data TML dan intensitas hujan dimasukkan ke dalam model dengan metode point sources dimana data diinput dalam bentuk time series yang tersebar di dalam domain. Model akan
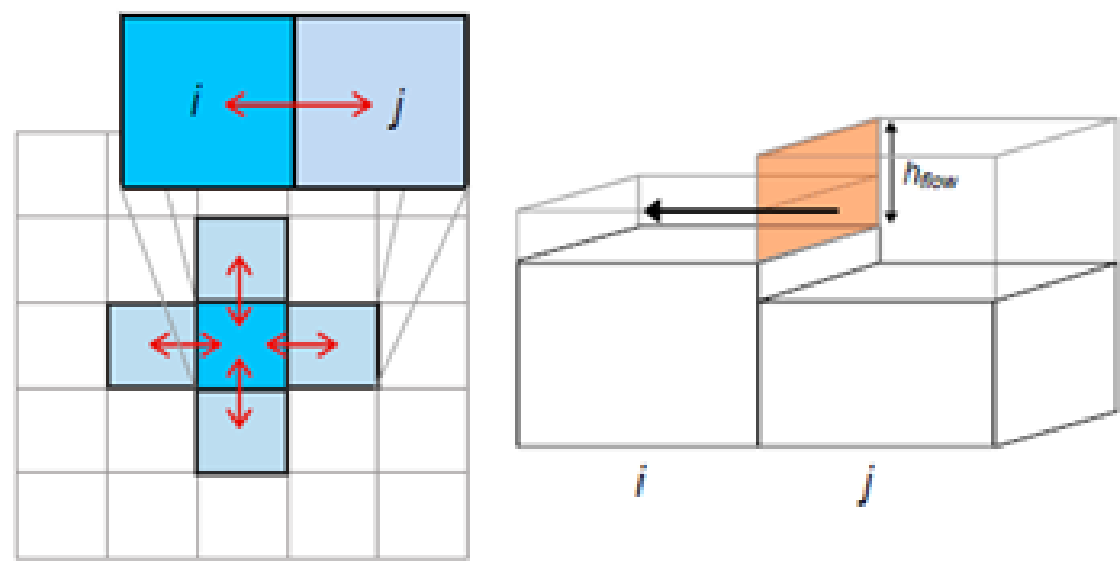

Gambar 3. Representasi aliran air antar sel pada model LISFLOOD FP.

Figure 3. Representation of water flow between cells in the LISFLOOD FP model. Sumber: Bates et al., 2005

JURNAL KELAUTAN NASIONAL, Vol 16, No 3, Desember 2021, Hal. 157-168 


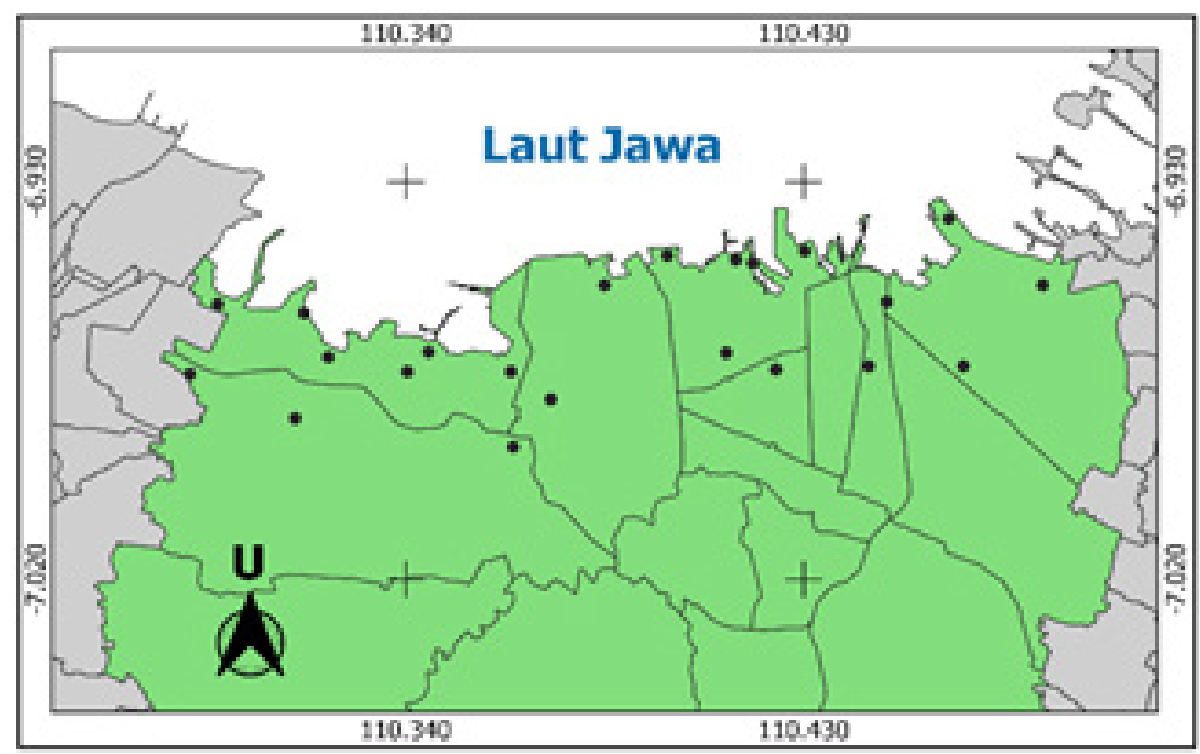

Gambar 4. Sebaran data intensitas hujan untuk model LISFLOOD FP.

Figure 4. Distribution of rain intensity data for the LISFLOOD FP model. Sumber: input model pada penelitian ini

dijalankan dengan dua skema, yaitu pertama running model dengan input data TML dan kedua running dengan input data TMLdan intensitas hujan. Sebaran data TML dan intensitas hujan yang digunakan masingmasing dapat dilihat pada Gambar 2 dan Gambar 4. Keluaran model LISFLOOD FP berupa sebaran spasial luasan area tergenang banjir rob. Luasan maksimum banjir rob pada kedua skema selanjutnya dianalisis untuk mengetahui bagaimana perbedaan luas banjir rob yang dihasilkan.

\section{HASIL DAN PEMBAHASAN}

\section{Analisis Digital Elevation Model (DEM) Pesisir Semarang}

Proses terjadinya banjir berkaitan erat dengan kondisi topografi suatu pesisir. Salah satu penyebab terjadinya banjir rob di pesisir Semarang adalah kondisi kontur tanah yang datar. Kondisi tanah yang datar menyulitkan drainase dalam mengalirkan air, terutama pada saat air pasang. Hal ini diperparah dengan adanya fenomena penurunan muka tanah sehingga wilayah yang tergenang banjir rob semakin bertambah setiap tahunnya (Ramadhany et al., 2012).

Pada penelitian ini data topografi model banjir rob diambil dari data DEM yang merepresentasikan visualisasi topografi atau ketinggian muka tanah (Putra \& Marfai, 2012). Data tersebut diperoleh dari data DEM Nasional (DEMNAS) BIG yang dibangun berdasarkan data IFSAR (resolusi $5 \mathrm{~m}$ ), data TERRASAR $-\mathrm{x}$ (resoulsi $5 \mathrm{~m}$ ) dan ALOS PALSAR (resolusi 11,25 m) yang ditambahkan dengan data Masspoint hasil stereoplotting. Data DEMNAS memiliki resolusi spasial 0,27 arc second $(8,1 \mathrm{~m})$ dengan datum vertikal EGM2008. Datum data DEMNAS diubah ke dalam datum MSL agar sesuai dengan datum vertikal TML.

Wilayah yang berbatasan langsung dengan laut diantaranya adalah Kecamatan Genuk, Gayamsari, Semarang Utara, Semarang Barat, serta Tugu. Ketinggian permukaan tanah pada jarak 0 hingga 1 $\mathrm{km}$ dari garis pantai umumnya berkisar antara $0 \mathrm{~m}$ hingga $5 \mathrm{~m}$. Sebagian wilayah pada kecamatan tersebut juga memiliki topografi yang cukup tinggi di sisi sebelah selatan sehingga aman dari banjir rob, seperti kecamatan Tugu dengan ketinggian tanah mencapai 50 $\mathrm{m}$, Semarang Barat dengan ketinggian tanah mencapai $70 \mathrm{~m}$, serta Genuk dengan ketinggian $17 \mathrm{~m}$. Kecamatan Semarang Tengah, Pedurungan, serta Semarang Timur secara geografi memang tidak berbatasan langsung dengan garis pantai, namun berdasarkan penelitian sebelumnya (Buchori et al., 2018), wilayah tersebut termasuk kedalam wilayah yang rawan terhadap banjir rob. Menurut Nusa (2020), banjir rob dapat terjadi secara tidak langsung, yaitu melalui saluran drainase yang tidak terawat dan retakan tanggul sungai sehingga bisa mencapai wilayah yang jauh dari garis pantai.

\section{Verifikasi Data Intensitas Curah Hujan dan Tinggi Muka Laut}

Data curah hujan yang digunakan dalam model banjir rob berasal dari prediksi model WRF. Sebaran spasial data tersebut sesuai dengan titik lokasi pada Gambar 4, 


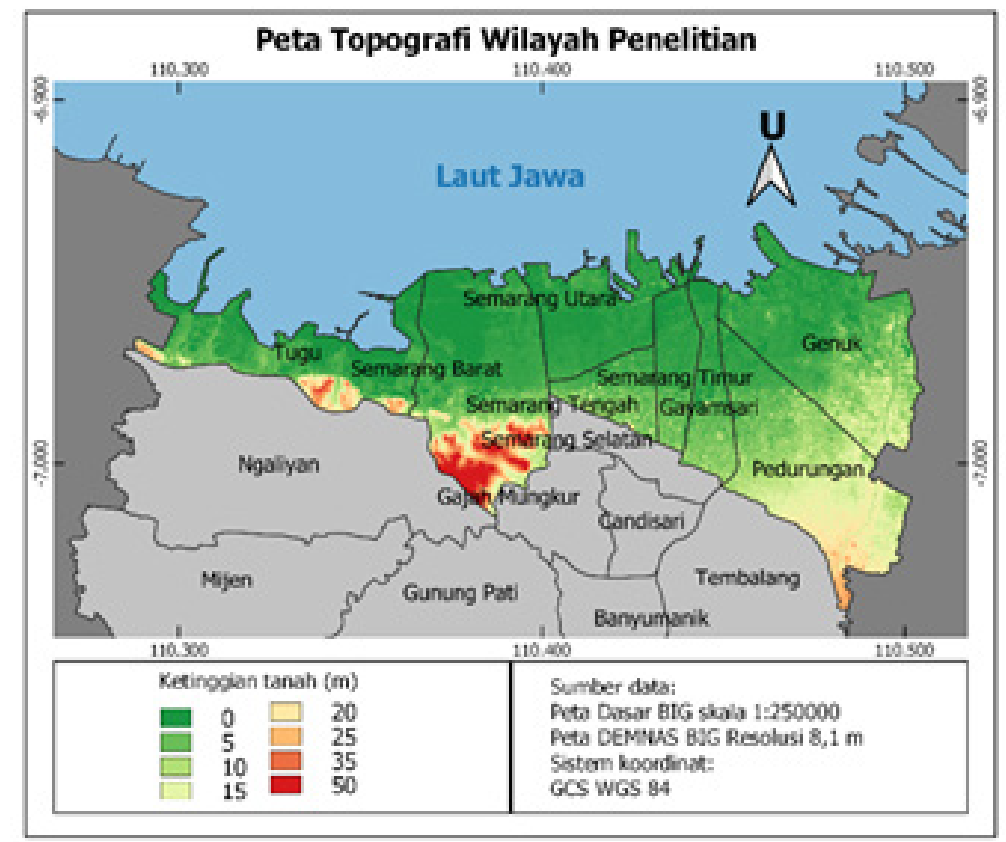

Gambar 5. Peta topografi wilayah penelitian.

Figure 5. Topographic map of the study area.

Sumber: Dokumentasi pribadi

sehingga curah hujan yang terjadi di luar domain tidak Pada saat intensitas hujan observasi mencapai nilai diperhitungkan dalam model. Gambar 6 menunjukkan grafik perbandingan intensitas hujan prediksi terhadap data observasi 3 - 5 Desember 2018 di Stasiun Meteorologi Maritim Tanjung Mas Semarang.

Pada 3 - 5 Desember 2018, tercatat curah hujan kumulatif selama tiga hari sebesar $117,1 \mathrm{~mm}$. Hujan dengan intensitas tertinggi terjadi pada 3 Desember 2018 jam 08 UTC. Curah hujan kumulatif tiga hari hasil prediksi WRF menunjukkan nilai yang jauh lebih sedikit, yaitu sebesar 58,6 mm. Berbeda dengan hasil observasi, intensitas hujan maksimum prediksi WRF terjadi pada 4 Desember 2018 jam 13 UTC. tertinggi, intensitas hujan WRF hanya menunjukkan nilai $0,17 \mathrm{~mm} / \mathrm{jam}$. Koefisien korelasi antara intensitas hujan prediksi dan observasi sebesar -0,046 yang menunjukkan hubungan pada tingkat sangat lemah, nilai RMSE sebesar $8,72 \mathrm{~mm} / \mathrm{jam}$, serta nilai linear bias sebesar $-0,813 \mathrm{~mm} / \mathrm{jam}$ yang menunjukkan hasil prediksi cenderung underestimate terhadap data observasi.

Model WRF pada penelitian ini disetting menggunakan opsi fisis Tropical Physics Suite. Opsi fisis tersebut didesain untuk wilayah tropis (Hastuti \& Paski, 2019), namun model WRF masih belum mampu memprediksi

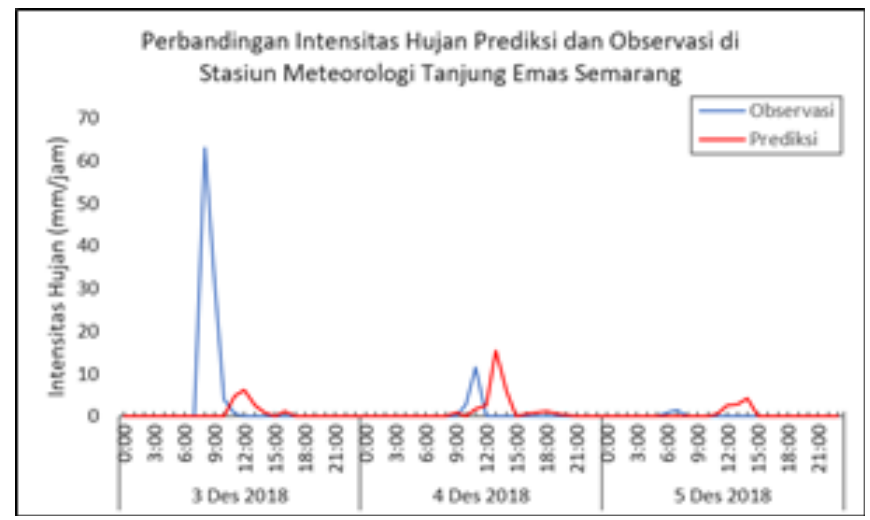

Gambar 6. Perbandingan intensitas curah hujan prediksi dan observasi Stasiun Meteorologi

Maritim Tanjung Mas 3 - 5 Desember 2018.

Figure 6. Comparison of the predicted and observed rainfall intensity of the Tanjung Mas Maritime Meteorological Station from 3 - 5 December 2018.

Sumber: hasil verifikasi model pada penelitian ini 


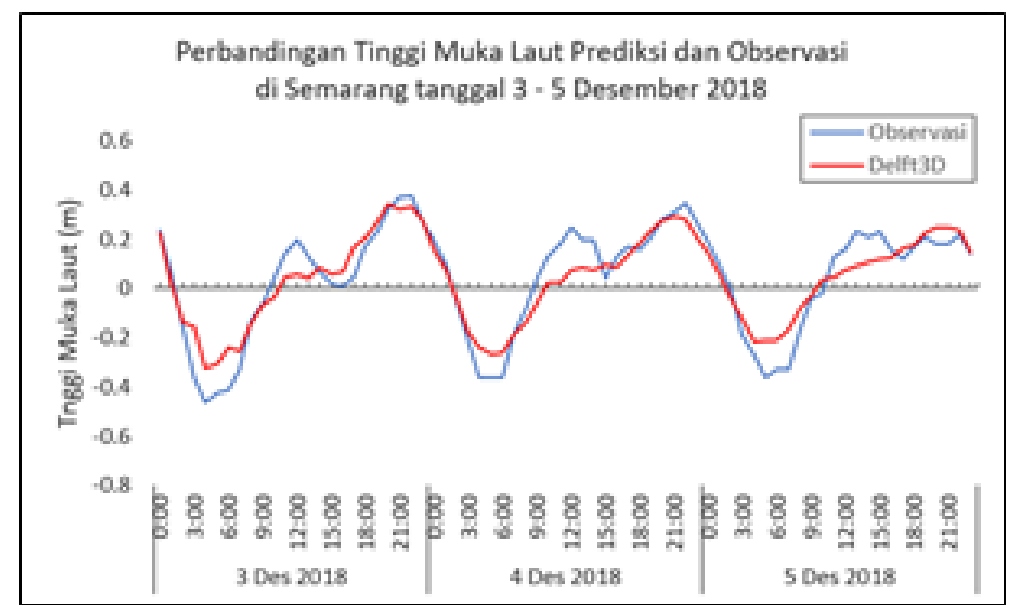

Gambar 7. Grafik perbandingan TML observasi dan prediksi di Semarang tanggal 3 - 5 Desember 2018.

Figure 7. Comparison chart of sea level observations and predictions in Semarang from 3 - 5 December 2018. Sumber: : hasil verifikasi model pada penelitian ini

intensitas hujan di wilayah Semarang dengan baik. Hal ini terlihat dari prediksi intensitas hujan WRF yang belum menunjukkan pola yang sesuai dengan data observasi serta nilainya yang cenderung underestimate.

Gambar 7 menunjukkan grafik perbandingan TML prediksi model Delft3D terhadap TML observasi di wilayah Semarang pada 3 - 5 Desember 2018. Secara umum, TML prediksi model Delft3D menunjukkan kemiripan pola dengan TML observasi. Nilai maksimum TML observasi mencapai $0,38 \mathrm{~m}$ yang terjadi pada 3 Desember 2018 jam 22 UTC, sedangkan TML minimum mencapai $-0,46 \mathrm{~m}$ yang terjadi pada tanggal 3 Desember 2018 jam 4 UTC. TML prediksi Delft3D mencapai nilai maksimum sebesar 0,34 $m$ yang terjadi pada 3 Desember 2018 jam 20 UTC, sedangkan TML minimum mencapai $-0,32 \mathrm{~m}$ yang terjadi pada 3 Desember 2018 jam 4 UTC. Koefisien korelasi berada pada tingkat sangat kuat sebesar 0,94, nilai RMSE sebesar $0,084 \mathrm{~m}$, serta linear bias sebesar $0,002 \mathrm{~m}$ yang menunjukkan prediksi TML cenderung overestimate terhadap data observasi.

Model Delft3D secara umum mampu memprediksi TML dengan performa yang baik. Berdasarkan penelitian sebelumnya, prediksi TML model Delft3D menunjukkan koefisien korelasi dengan nilai lebih dari 0,9 atau berada pada tingkat sangat tinggi. Meskipun demikian, model hidrodinamika seperti Delft3D sensitif terhadap perubahan kondisi batas serta kondisi awal model, sehingga quality control data perlu diperhatikan untuk menjaga performa model (Parker, 2007; Mundir, 2013; Novico et al., 2016; Atmaja et al., 2019).

\section{Prediksi Banjir Rob Model LISFLOOD FP}

Data prediksi intensitas curah hujan dan prediksi TML selanjutnya digunakan sebagai input model LISFLOOD FP untuk mengetahui daerah mana yang berpotensi tergenang banjir rob. Pada penelitian ini, model LISFLOOD FP dijalankan dengan dua variasi, yaitu model tanpa memperhitungkan data intensitas curah hujan dan model dengan memperhitungkan data intensitas curah hujan. Variasi keluaran model tersebut selanjutnya dibandingkan untuk mengetahui perbedaan luasan daerah yang berpotensi terdampak banjir rob. Gambar 8 dan 9 merupakan prediksi wilayah yang berpotensi terkena dampak banjir rob pada saat mencapai nilai maksimum, yaitu 4 Desember 2018 jam 23.00 UTC.

Prediksi banjir rob untuk model tanpa memperhitungkan data intensitas curah hujan dapat dilihat pada Gambar 8. Banjir rob terpantau menggenangi sejumlah wilayah secara sporadis. Kedalaman air yang menggenang bervariasi antara $0,2 \mathrm{~m}$ hingga $0,8 \mathrm{~m}$ di Semarang bagian barat, $0,1 \mathrm{~m}$ hingga 1,5 di Semarang bagian tengah, serta $0,1 \mathrm{~m}$ hingga $0,7 \mathrm{~m}$ di Semarang bagian timur. Sedangkan untuk model banjir rob dengan memperhitungkan intensitas curah hujan menunjukkan adanya genangan banjir rob dengan kedalaman $0,1 \mathrm{~m}$ hingga $0,7 \mathrm{~m}$ di wilayah Semarang bagian barat, 0,2 $\mathrm{m}$ hingga $1,5 \mathrm{~m}$ di Semarang bagian tengah, dan $0,1 \mathrm{~m}$ hingga $0,8 \mathrm{~m}$ di wilayah Semarang bagian timur.

Secara umum, baik model banjir rob tanpa dan dengan memperhitungkan intensitas curah hujan memiliki pola sebaran dan luas yang hampir sama, kecuali di wilayah Semarang bagian timur. Pada wilayah tersebut terpantau adanya daerah banjir rob yang lebih luas yang ditandai dengan lingkaran merah pada Gambar 9. Hal 

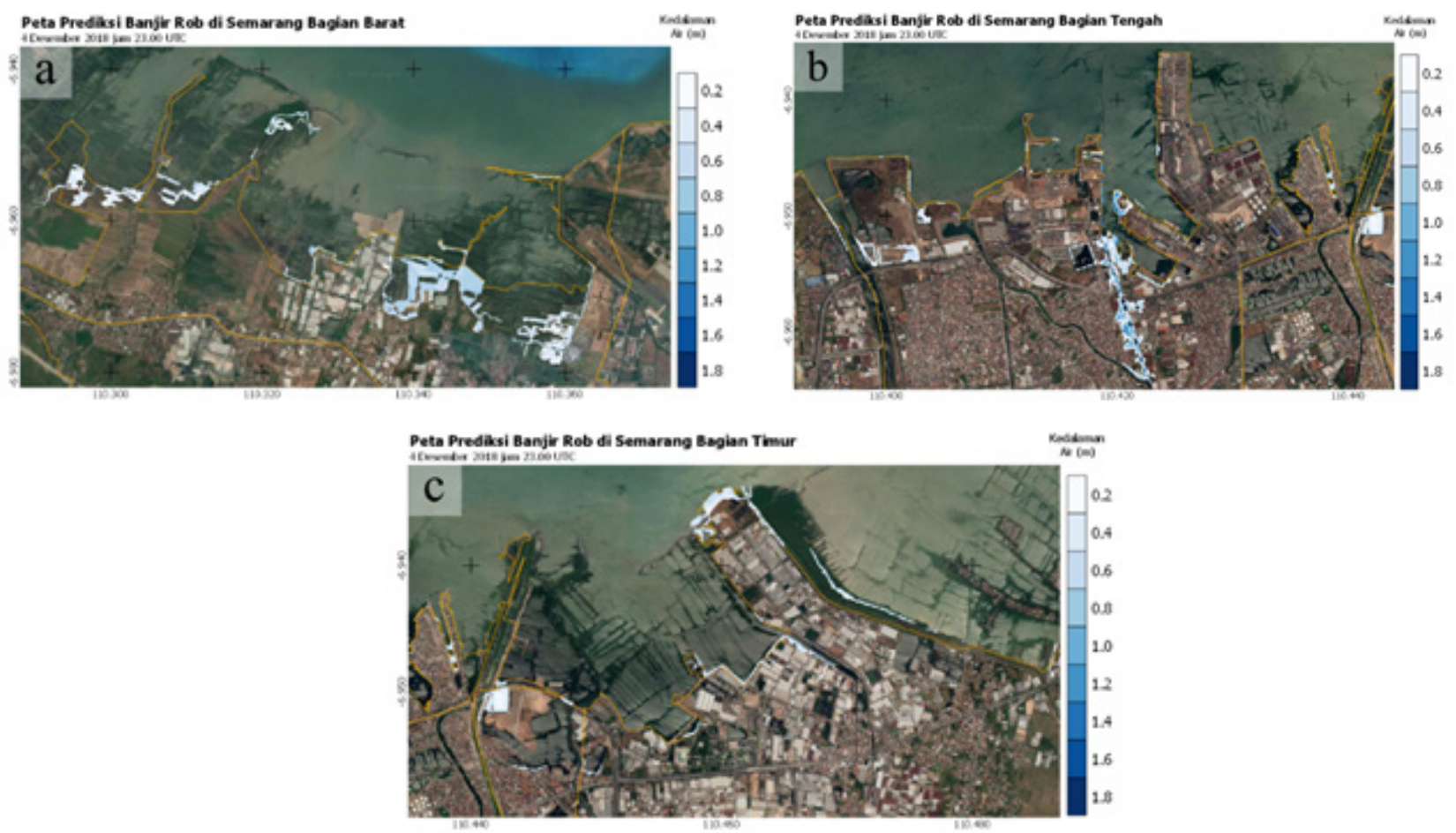

Gambar 8. Prediksi banjir rob tanpa data hujan jam 23.00 UTC 4 Desember 2018 untuk wilayah: (a) Semarang bagian barat, (b) Semarang bagian tengah, dan (c) Semarang bagian timur.

Figure 8. Prediction of tidal flooding without rain data at 23.00 UTC on December 42018 for the following areas: (a) western Semarang, (b) central Semarang, and (c) eastern Semarang.

Sumber: hasil simulasi pada penelitian ini
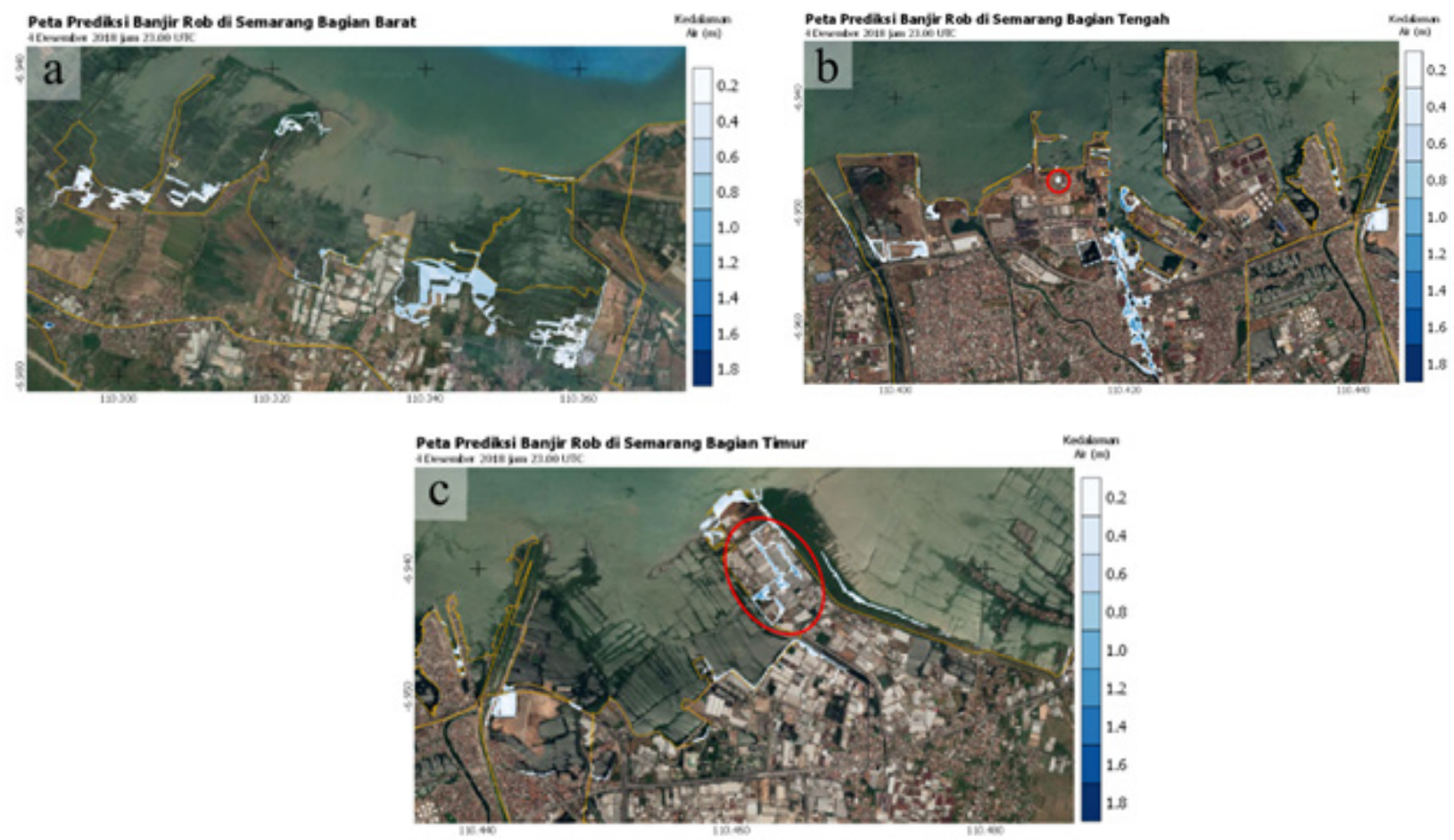

Gambar 9. Prediksi banjir rob dengan data hujan jam 23.00 UTC 4 Desember 2018 untuk wilayah: (a) Semarang bagian barat, (b) Semarang bagian tengah, dan (c) Semarang bagian timur.

Figure 9. Prediction of tidal flooding with rain data at 23.00 UTC on December 42018 for the following areas: (a) western Semarang, (b) central Semarang, and (c) eastern Semarang.

Sumber: hasil simulasi pada penelitian ini 
Tabel 1. Perbandingan luas maksimum (m2) daerah banjir rob untuk model tanpa data hujan dan dengan data hujan Table 1. Comparison of the maximum area (m2) of coastal inundation area for models without rainfall data and with rainfall data

\begin{tabular}{lll}
\hline Kecamatan & Tanpa data hujan & Dengan data hujan \\
\hline Gayamsari & $4.73 \mathrm{E}+04$ & $4.75 \mathrm{E}+04$ \\
Genuk & $6.42 \mathrm{E}+04$ & $1.35 \mathrm{E}+05$ \\
Semarang Barat & $8.29 \mathrm{E}+03$ & $8.29 \mathrm{E}+03$ \\
Semarang Utara & $2.64 \mathrm{E}+05$ & $2.67 \mathrm{E}+05$ \\
Tugu & $1.01 \mathrm{E}+06$ & $1.02 \mathrm{E}+06$ \\
Total & $1.40 \mathrm{E}+06$ & $1.47 \mathrm{E}+06$ \\
\hline \multicolumn{2}{l}{ Sumber: hasil analisis pada penelitian ini }
\end{tabular}

ini mengindikasikan bahwa curah hujan memberikan pengaruh terhadap luasan banjir rob, khususnya pada saat terjadi hujan lebat. Mengingat rendahnya akurasi prediksi intensitas curah hujan dengan nilai yang cenderung dibawah hasil observasi, ada kemungkinan banjir rob yang dihasilkan memiliki luasan yang lebih luas.

Untuk mengetahui daerah mana saja yang tergenang banjir rob berdasarkan prediksi model LISFLOOD FP secara detail dapat dilihat dalam Tabel 1. Tabel 1 menunjukkan perbandingan luas maksimum banjir rob untuk model tanpa memperhitungkan data hujan dan dengan memperhitungkan data hujan. Terdapat 5 kecamatan yang terdampak banjir rob, diantaranya adalah Gayamsari, Genuk, Semarang Barat, Semarang Utara, dan Tugu. Luas banjir rob tertinggi terdapat pada Kecamatan Tugu, sedangkan luas banjir rob terendah terdapat pada Kecamatan Gayamsari.

Total luas wilayah terdampak banjir rob untuk model tanpa data hujanmencapainilai $1,40 \mathrm{E}+06 \mathrm{~m}^{2}$, sedangkan untuk model dengan data hujan menunjukkan nilai sebesar $1,47 \mathrm{E}+06 \mathrm{~m}^{2}$. Perbedaan luas banjir rob pada kedua model tidak terlalu signifikan, yaitu sebesar $7,76 \mathrm{E}+04 \mathrm{~m}^{2}$ atau $5,6 \%$ lebih luas dibanding model tanpa data hujan. Hal tersebut kemungkinan disebabkan oleh rendahnya nilai prediksi intensitas curah hujan yang menjadi input model. Sementara itu, intensitas curah hujan hasil observasi cukup tinggi sehingga luas daerah banjir rob sebenarnya kemungkinan lebih luas dibanding hasil keluaran model.

Secara umum, model LISFLOOD FP mampu memprediksi banjir rob dengan luasan banjir yang mendekati kondisi di lapangan (Bates et al., 2005; Shustikova et al., 2019; Fatapour et al., 2020). Model banjir rob pada penelitian ini belum diverifikasi dengan data di lapangan, sehingga diperlukan penelitian lebih lanjut untuk mengetahui akurasi dari model tersebut. Disisi lain, akurasi prediksi intensitas hujan sebagai input data model LISFLOOD FP juga masih rendah. Hal tersebut membutuhkan kajian lebih lanjut karena ketidakpastian prediksi intensitas curah hujan berkontribusi tinggi terhadap error yang dihasilkan model banjir (Cristiano et al., 2017).

\section{KESIMPULAN DAN SARAN}

Pada penelitian ini prediksi banjir rob dilakukan menggunakan model LISFLOOD FP dengan data masukan berupa prediksi TML serta intensitas hujan. Prediksi TML diperoleh dari model Delft3D menunjukkan performa yang baik dengan koefisien dengan koefisien korelasi berada pada tingkat sangat kuat serta dengan nilai error yang relatif kecil. Sementara itu untuk prediksi intensitas hujan model WRF secara umum belum bisa memberikan hasil yang memuaskan. Prediksi intensitas hujan memberikan hasil yang lebih rendah (underestimate) serta belum bisa mengikuti pola data observasi.

Prediksi banjir rob model LISFLOOD FP dijalankan dalam 2 skema, yaitu model dengan data masukan prediksi TML serta model dengan data masukkan prediksi TML dan intensitas hujan. Variasi skema digunakan untuk mengetahui pengaruh data intensitas hujan terhadap luasan banjir rob. Prediksi banjir rob untuk kedua skema model secara umum menunjukkan kedalaman genangan yang hampir sama, yaitu berkisar antara 0,2 - 1,5 m. Namun jika ditinjau dari luasan daerah yang terdampak, model dengan inputan data hujan menunjukkan luasan banjir rob sebesar 5,6\% lebih luas dibandingkan dengan model banjir rob tanpa memperhitungkan data hujan.

\section{UCAPAN TERIMA KASIH}

Ucapan terima kasih kami ucapkan kepada semua pihak yang telah membantu terlaksananya seluruh 
kegiatan penelitian sampai selesai.

\section{DAFTAR PUSTAKA}

Atmaja, R. R., Radjawane, I., \& Tarya, A. (2019). POLAARUS PASANG SURUT DI PERAIRAN WAKATOBI. Prosiding Seminakel, 1(1), 24-31.

Aulia, N. N., Gunawan, P. H., \& Rohmawati, A. A. (2018). Prediksi Curah Hujan Menggunakan Gerak Brown dan Rataan Tahunan Data Pada Missing Values. Indonesia Journal on Computing (Indo-JC), 3(2), 71-82.

Bates, P. D., Dawson, R. J., Hall, J. W., Horritt, M. S., Nicholls, R. J., Wicks, J., \& Hassan, M. A. A. M. (2005). Simplified two-dimensional numerical modelling of coastal flooding and example applications. Coastal Engineering, 52(9), 793810.

Buchori, I., Sugiri, A., Mussadun, M., Wadley, D., Liu, Y., Pramitasari, A., \& Pamungkas, I. T. (2018). A predictive model to assess spatial planning in addressing hydro-meteorological hazards: A case study of Semarang City, Indonesia. International journal of disaster risk reduction, 27(3), 415-426. DOI:10.1016/j.ijdrr.2017.11.003

Cristiano, E., ten-Veldhuis, M. C., \& van de Giesen, N. (2017). Spatial and temporal variability of rainfall and their effects on hydrological response in urban areas-a review. Hydrology \& Earth System Sciences, 21(7), 3859-3878. DOI:10.5194/hess-21-3859-2017

Crossland, C. J., Kremer, H. H., Lindeboom, H., Crossland, J. I. M., \& Le Tissier, M. D. (Eds.). (2005). Coastal fluxes in the Anthropocene: the land-ocean interactions in the coastal zone project of the International GeosphereBiosphere Programme. Springer Science \& Business Media.

Dabrowa, A., Neal, J. C., \& Bates, P. D. (2015). Floods and Storms Practical Exercises. In HydroMeteorological Hazards, Risks and Disasters (pp. 213-229). Elsevier.

Deltares. (2014a). Delft3D-Flow User Manual. Delft: Deltares.
Deltares. (2014b). Introductory Course Hydrodynamics. Delft: Deltares.

Fatapour, E., Afroos, A., Nejad, B. A., Saremi, A., \& Khosrowjerdi, A. (2020). Evaluation of the TwoDimensional Hydraulic Model LISFLOOD-FP in Floodplain Predictions of Various Return Periods. Archives of Pharmacy Practice, 1, 84.

Hastuti, M. I., \& Paski, J. I. A. (2019). Assimilation of Weather Radar Data Using WRF 3DVar Modelling for Rainfall Prediction. IOP Conference Series Earth and Environmental Science, 303(1), 012047. DOI:10.1088/17551315/303/1/012047

IPCC. (2019). Summary for Policymakers. In: IPCC Special Report on the Ocean and Cryosphere in a Changing Climate. In press.

Kobayashi, H. (2003). Vulnerability assessment and adaptation strategy to sea-level rise in Indonesian coastal urban areas. National Institute for Land and Infrastructure Management, Japan.

Kraas, F. (2007). Megacities and global change: key priorities. The Geographical Journal, 173(1), 79-82.

Kumar,P.D.(2006). Potential vulnerability implications of sea level rise for the coastal zones of Cochin, southwest coast of India. Environmental Monitoring and Assessment, 123(1-3), 333.

Marfai, M. A., \& King, L. (2008). Tidal inundation mapping under enhanced land subsidence in Semarang, Central Java Indonesia. Natural hazards, 44(1), 93-109.

Marfai, M. A., Mardiatno, D., Cahyadi, A., Nucifera, F., \& Prihatno, H. (2013). Pemodelan Spasial Bahaya Banjir Rob Berdasarkan Skenario Perubahan Iklim dan Dampaknya di Pesisir Pekalongan. Jurnal Bumi Lestari, 13(2), 244256.

Masselink, G., \& Gehrels, R. (Eds.). (2014). Coastal environments and global change. John Wiley \& Sons.

Mundir. (2013). Statistika Pendidikan. Jember: Pustaka Pelajar 
Neal, J., Schumann, G., \& Bates, P. (2012). A subgrid channel model for simulating river hydraulics and floodplain inundation over large and data sparse areas. Water Resources Research, 48(11), W1506.

Novico, F., Astjario, P., \& Bachtiar, H. (2016). Kondisi Arus Pasang Surut dan Erosi-Sedimentasi di Sekitar Garis Pantai Depan PLTU Tarahan lampung menggunakan DELFT 3D Versi 3.28. Jurnal Geologi Kelautan, 11(1), 39-54.

Nugroho, S. H. (2013). Prediksi luas genangan pasang surut (rob) berdasarkan analisis data spasial di Kota Semarang, Indonesia. Jurnal Lingkungan dan Bencana Geologi, 4(1), 71-87.

Nusa, A. B. (2020). Pemodelan Peta Rawan Banjir Rob Di Belawa. Jurnal Pembangunan Perkotaan, $8(1), 23-32$.

Parker, B. B. (2007). Tidal analysis and prediction. Maryland: National Oceanic and Atmospheric Administration.

Putra, D. R., \& Marfai, M. A. (2012). Identifikasi Dampak Banjir Genangan (Rob) Terhadap Lingkungan Permukiman Di Kecamatan Pademangan Jakarta Utara. Jurnal Bumi Indonesia, 1(1).

Ramadhany, A. S., Subardjo, P., \& Suryo, A. A. D. (2012). Daerah Rawan Genangan Rob di Wilayah Semarang. Journal of Marine Research, l(2), 174-180.

Robertson, A., \& Vitart, F. (Eds.). (2018). Sub-seasonal to Seasonal Prediction: The Gap Between Weather and Climate Forecasting. Elsevier.

Safril, A., Hadi, T. W., Hadi, S., \& Kasih, B. T. H. (2013). Prediksi hujan bulanan menggunakan adaptive statistical downscaling. Jurnal Meteorologi dan Geofisika, 14(1), 25-31.

Sanjaka, P. A., Widada, S., \& Prasetyawan, I. B. (2013). Pemodelan Inundasi (Banjir Rob) di Pesisir Kota Semarang Dengan Menggunakan Model Hidrodinamika. Journal of Oceanography, 2(3), 353-360.

Shustikova, I., Domeneghetti, A., Neal, J. C., Bates, P., \& Castellarin, A. (2019). Comparing 2D capabilities of HEC-RAS and LISFLOOD-FP on complex topography. Hydrological Sciences Journal, 64(14), 1769-1782.

Skamarock, W. C., Klemp, J. B., Dudhia, J., Gill, D. O., Barker, D. M., Duda, M. G., Huang, X., \& Powers, J. G. (2008). A description of the advanced research WRF Version 3, Mesoscale and Microscale Meteorology Division. National Center for Atmospheric Research, Boulder, Colorado, USA, 6.

Susanti, B. T., Listiati, E., \& Mulyani, I. M. (2017). Partisipasi Masyarakat dalam pembuatan rumah bambu yang adaptif terhadap banjir dan rob, studi kasus di wilayah Kemijen, Prosiding Seminar Nasional Arsitektur Populis, Semarang.

Ward, P. J., Marfai, M. A., Yulianto, F., Hizbaron, D. R., \& Aerts, J. C. J. H. (2011). Coastal inundation and damage exposure estimation: a case study for Jakarta. Natural Hazards, 56(3), 899-916.

Wolf, J. (2008). Coupled wave and surge modelling and implications for coastal flooding. Advances in Geosciences, 17. DOI:10.5194/ adgeo-17-19-2008 
